\title{
ROLE OF ICT IN E-COMMERCE BUSINESS EMERGING
}

\author{
Dr. Mrs. Mrunali S. Deshpande
}

\author{
Assistant Professor \\ Bhawabhti Mahavidyalay, Amgaon, Dist- Gondia
}

\begin{abstract}
Role of ICT in E-Commerce Business developing are inseparable terms as the e-commerce industry is absolutely dependent on ICT and e-commerce for its operations and intensification. E-commerce is referred to as application of ICT in business and E-commerce. ICT is term which involves usage of computers, including hardware, software, application and networks used to communicate, store and cover the requisite information. The concept of e-Business has been evolving since a number of years and is causative to the economic growth of several developing economies. The approaching for the growth of e-commerce in the developing countries is very high but ICT being the precondition, lack of ICT infrastructure hampers the rate of its growth. The growth of e-commerce is primarily dependent upon the boost in ICT infrastructure. The Smart mobile phone market and Internet diffusion has proved to be a catalyst for growth of ecommerce industry. This paper focus to discuss the role of ICT and ecommerce its services in driving ecommerce industry in developing countries like India and the shift from e-commerce to commerce in large scale in the near future.
\end{abstract}

Keywords: ICT; e-commerce; m-commerce, E-Business

\section{INTRODUCTION}

Technology continues to be a transformative force and is changing the way individuals live, interact, and work. ICT are changed the future approach of doing business globally and the scenario is identical for India and other developing economies. ICT is very different term which involves usage of computers, including hardware, application, software and networks used to communicate, store and manage the requisite data. The applications of ICT are very varied and one such area is electronic commerce. Today e-commerce and computer has become an integral part of everyday life. Accessibility to e-commerce platforms is not a privilege but rather a necessity for most people, particularly in the urban areas. There are alternative e-commerce platforms available for almost every aspect of our lives, starting from purchasing of everyday household items to online shares and commodities. "e-commerce" is defined as the application of information and ICT which support all the activities and realms of business. The concept of e-commerce has been growing since a number of years and is causative to the economic growth of several developed and developing economies. The key factors responsible for the growth of e- commerce ICT is a leading one. ICT and e-commerce are inseparable terms as the ecommerce industry is absolutely dependent on ICT and commerce for its operations and intensification. The concept of e-commerce is very flexible and therefore covers all possible uses of information and communication technologies. ICT infrastructure and services is not a major issue in developed countries but for developing countries like India it sometime seems 
to be a barrier in the growth of electronic commerce. e-business define sale or purchase of goods and services conducted over internet or TV channels. The goods are ordered electronically the payments or online payment or delivery of goods and services need not be conducted online. More usage of internet, high educational standards, changing life style, day to day life and economic growth of the country are the few major reasons for the demand of ecommerce techniques and implements. Among these techniques online shopping has a vital role. Among these reasons the growth of internet and its increased diffusion into the rural areas of India is the significant factor for the exponential growth of e-commerce and online shopping. The growing breach of technology facilitators such as Internet connections, software, broadband and third generation services, laptops, smartphones, mobile phone, tablets and dongles, Wi-Fi , coupled with ever-increasing acceptance to the idea of virtual shopping, is set to steer the e-commerce industry. The $\mathrm{B} 2 \mathrm{C}$ segment seems to be most promising and is expected to lead the e-commerce market in the near future, in addition to the growing of ICT infrastructure the easy payment modes and innovative policies are some of the other factors behind this growth. In future, the sector is planning to offer much more revolutionary practices such as transacting with the help of Mobile money, and having access to virtual trial rooms. Ecommerce focuses on the use of ICT to facilitate the activities and associations of the business with customers.

\section{The Various Classification Of E-Commerce Business}

Business to Business (B2B): B2B is e-commerce businesses between one business firm to another business such as a manufacturer and a wholesaler or between a wholesaler and a retailer.

Business to Consumer (B2C): B2C is e-commerce businesses between a business firm and a consumer or customer such as between a manufacturer and consumer or retailer and consumer.

Consumer to Business (C2B): e-commerce businesses in which individual customers offer to sell products and services to companies who are prepared to purchase them. This business model is the differing of the traditional B2C model.

Consumer to Consumer (C2C): $\mathrm{C} 2 \mathrm{C}$ is e-commerce businesses in which individual customers offer to sell products and services to other individuals who are prepared to purchase them.

\section{Commerce Portals:}

(a) Multi Product E-Commerce Portals: Many internet portals provide several all types of goods and services in a single site. These e-commerce portals provide goods and services, facility in a variety of categories like apparel, accessories, health and beauty products, books and magazines, computers and peripherals, online shopping, product, vehicles, consumer electronics, household appliances, jewellery, etc. Some portals offer the platform to sell and purchase the used articles like electronics, vehicles, furniture etc. 
(b) Single Product E-Commerce Portals: (1) Stock and Shares Trading (2) Real Estate (3) Travel and Tourism industry (4) Matrimony (5) Job Portals. (6) Money Market Etc.

Role of Banks: Net banking: E commerce is promoted by Internet banking that facilitates the online funds transfer.

The net banking facility is available for savings account holders as well as current account holders. Customers can use this facility for online bill payment, Ticket booking, purchase of goods etc.

Credit/Debit Cards: Banks facilitate E-commerce by providing the most vital trade instrument, namely the Credit or Debit Card these help the customers to pay for their purchases made online.

Mobile Banking: Mobile banking permits customers of bank to conduct a financial transactions over a mobile device like mobile phone or tablet.

Following terms use of mobile users.

1. Online Shopping Trends. The e-commerce and online shopping is getting a noticeable growth. The companies and MNCs could not neglect the importance of online shopping for their product branding, promotion and increased sales. It has been observed that Indian consumers have matured over the years and increased their acceptance for various payment approaches such as net banking and prepaid wallets. E-commerce prospect has thus widened due to recognition of online shopping as a safe shopping medium. Of the total 200.0 million credit and debit card holders, just about 10.0 million people transact online, indicating a huge untapped market.

2. Security With the help of structured questionnaire, the study has been done. Each of the questions covers the valid reasons to find out the online shopping factors, influences and demands. The data analysis of the questioner gives a very positive sign about the security aspect of the e commerce industry especially online shopping. Customers find online shopping safe and secure and feel comfortable to give their details and make online

\section{CONCLUSION}

The given information that how e-commerce industry is rapidly growing in the developing country like India and other country which has an immense potential for inline shopping as the population is young and enthusiastic and open to the inventive ways of shopping provided by Information and Communication Technology in commerce or e- business . The very important fact is the shift from e-commerce to m-commerce, which has shown a remarkable growth and with this growing trend the future of e-commerce industry is very secure and bright. it is expected that India will leave the countries like US and Japan and give a tough fight to China. The credit goes to the growing ICT infrastructure and developing the e-commerce or ebusiness. 


\section{Reference:}

- [Srivastava and Singh, 2013] Nishant Srivastava and Shashank Singh (2013)

- E-Business: Scope and challenges in India, International Journal of Business and Management Invention ISSN Volume 2 Issue 8, August. 2013 PP.01-08.

- [Forrestor Research, 2012] Forrestor Research, Trends in India's e-Commerce Market: Report provided by Forrestor Research for ASSOCAM's 2nd National Conference on eCommerce 2012. [Mitra, 2013

- E-COMMERCE IN INDIA- A REVIEW, International Journal of Marketing, Financial Services \& Management Research, ISSN 2277- 3622 Vol.2, No. 2, February (2013).

- [RBI Report, 2014] RBI, Mobile Banking: Technical Committee on Mobile Banking - Report, 2014.

- [IAMAI, 2013] Internet and Mobile Association of India (IAMAI) and IMRB International report, 2013. [TRAI, 2014] TELECOM REGULATORY

- Akbar, Ali, ST. 2006. Quick Guide to Mastering Information and Communication Technology. Gava Media Yogyakarta

- Jr Mcleod, Raymond. 2001. Indonesian version of the Management Information System. Seventh edition. PT Prenhallindo. Jakarta

- Nugroho, Adi. 2006. E-commerce Understanding Maya World Modern Trade. Informatics. Bandung.

- Lupiyoadi, Rambat. 2004. Entrepreneurship: From Mindset to Strategy. Institution University of Indonesia Publisher.

- Sukardi, Faith S. 1991. Planned Intervention of Environmental Factors against Formation of Entrepreneurial traits. Dissertation. Jakarta: Postgraduate Faculty UI.

- Sukirno, Sadono. 2004. Introduction to Business. Prenada Media.

- Prasetijono WM Joedo in Developing Institutional Capabilities of Small Businesses in Facing the Era of Free Trade. Paper in The Asia Discussion Foundation and ISEI, August 22-23 1998

- Mudradjat Kuntjoro, "Small Businesses in Indonesia: Profiles, Problems and Strategies Empowerment. Studium Generale at STIE Cooperation, Yogyakarta, 18 November 2000.

- Utami, Setyaningsih Sri. 2010. Effects of Information Technology on Business Development. AUTHORITY OF INDIA, Indian Telecom Services Performance [Advancements in Information Technology-RIAIT'2014] 